\title{
Effects of calcium and magnesium silicate on the absorption of silicon and nutrients in wheat
}

\section{Silicato de cálcio e magnésio na absorção de silício e nutrientes no trigo}

\author{
Marcos Vinicius Mansano Sarto ${ }^{1 *}$; Maria do Carmo Lana²; Leandro Rampim³; Jean \\ Sérgio Rosset ${ }^{4}$; Jaqueline Rocha Wobeto Sarto ${ }^{5}$; Doglas Bassegio ${ }^{6}$
}

\begin{abstract}
Wheat is a plant that accumulates silicon (Si). The application of silicon to the soil may influence the absorption of nutrients by the plant and, therefore, its nutritional balance. In this study, we aimed to evaluate the effects of calcium and magnesium silicate $\left(\mathrm{CaSiO}_{3} / \mathrm{MgSiO}_{3}\right)$ on the ability of wheat (Triticum aestivum L.) to utilize silicon and absorb nutrients from soils collected in the state of Paraná, Brazil. The experiment was carried out in a greenhouse using 8-L plastic pots and three types of soil. Treatments were arranged in randomized blocks $(3 \times 5$ factorial design): three soils [Rhodic Acrudox (Ox1), Rhodic Hapludox (Ox2), and Arenic Hapludult (Ult)], five silicate rates $(0,1,2,4$, and $6 \mathrm{t}$ $\mathrm{ha}^{-1}$ of calcium/magnesium silicate), and four replications were performed. The effects of calcium and magnesium silicate on the concentrations of $\mathrm{Si}, \mathrm{N}, \mathrm{P}, \mathrm{K}^{+}, \mathrm{Ca}^{2+}, \mathrm{Mg}^{2+}, \mathrm{S}, \mathrm{Cu}^{2+}, \mathrm{Zn}^{2+}, \mathrm{Fe}^{2+}$, and $\mathrm{Mn}^{2+}$ within leaves were evaluated. Silicon concentrations in wheat leaves and stems increased with increasing rates of calcium and magnesium silicate applied to the soil. Wheat shoots accumulated averages of $28.2 \%$ (Ox1), 60.61\% (Ult), and 74.14\% (Ox2) of the Si from the silicate applied to the soil. Silicate fertilization increased the amount of $\mathrm{Ca}^{+2}$ and $\mathrm{Mg}^{+2}$ within leaves and reduced the amount of $\mathrm{Zn}^{2+}$ and $\mathrm{Mn}^{2+}$ within leaves. Calcium and magnesium silicate prevented excessive amounts of $\mathrm{Mn}^{2+}$ from being absorbed by wheat, improving the balance in the absorption of this nutrient.
\end{abstract}

Key words: Leaf nutrition. Si. Silicon absorption. Wheat. Triticum aestivum L.

\section{Resumo}

O trigo é uma planta acumuladora de silício (Si). A aplicação de silício pode influenciar a absorção de nutrientes pela planta e, consequentemente, o balanço nutricional da cultura. O objetivo deste trabalho foi avaliar o efeito da aplicação de doses de silicato de cálcio e magnésio $\left(\mathrm{CaSiO}_{3} / \mathrm{MgSiO}_{3}\right)$ no aproveitamento de silício e absorção de nutrientes pelo trigo em solos do estado do Paraná, Brasil. O experimento foi realizado em vasos plásticos de $8 \mathrm{~L}$ em estufa, com três tipos de solos. O delineamento experimental utilizado foi de blocos ao acaso, em esquema fatorial $5 \times 3$, com quatro repetições. Os

Dr., Universidade Estadual Paulista, UNESP, FCA, Botucatu, SP, Brasil. E-mail: marcos_sarto@hotmail.com

2 Prof ${ }^{a}$ Associada, Centro de Ciências Agrárias, CCA, Universidade Estadual do Oeste do Paraná, UNIOESTE, Bolsista CNPq, Marechal Cândido Rondon, PR, Brasil. E-mail: maria.lana@unioeste.br

3 Prof. Dr., Universidade Estadual do Centro-Oeste, Guarapuava, PR, Brasil. Bolsista Produtividade CNPQ Nível 2. E-mail: rampimleandro@yahoo.com.br

4 Prof. Dr., Universidade Estadual de Mato Grosso do Sul, UEMS, Mundo Novo, MS, Brasil. E-mail: rosset@uems.br

5 Dr ${ }^{\mathrm{a}}$ Zootecnia, Faculdade de Medicina Veterinária e Zootecnia, UNESP, Botucatu, SP, Brasil. E-mail: jaque_wobeto@hotmail. com

6 Prof. Dr., Universidade Estadual do Oeste do Paraná, UNIOESTE, Cascavel, PR, Brasil. E-mail: doglas14@hotmail.com

* Author for correspondence 
tratamentos foram dispostos em um delineamento em blocos casualizados, em esquema fatorial $3 \times 5$ : três solos [Latossolo Vermelho eutroférrico (LVef), Latossolo Vermelho distroférrico (LVd) e Argissolo Vermelho-Amarelo eutrófico (PVAe)] e cinco doses de silicato (0, 1, 2, 4 e $6 \mathrm{t}^{\mathrm{a}} \mathrm{a}^{-1}$ de silicato de cálcio/ magnésio), com quatro repetições. Avaliou-se o efeito do silicato de cálcio e magnésio no teor foliar de: $\mathrm{Si}, \mathrm{N}, \mathrm{P}, \mathrm{K}^{+}, \mathrm{Ca}^{2+}, \mathrm{Mg}^{2+}, \mathrm{S}, \mathrm{Cu}^{2+}, \mathrm{Zn}^{2+}, \mathrm{Fe}^{2+} \mathrm{e} \mathrm{Mn}^{2+}$. A aplicação de silicato de cálcio e magnésio aumenta os teores de Si nas folhas e colmos do trigo, refletindo sua aplicação no solo. A quantidade de Si acumulada pela parte aérea do trigo proveniente do silicato aplicado variou entre $28,2 \%, 60,61 \%$ e 74,14 \%, nos solos LVef, PVAe e LVd, respectivamente. A adubação silicatada aumentou os teores de $\mathrm{Ca}^{+2} \mathrm{e} \mathrm{Mg}^{+2} \mathrm{e}$ reduziu os teores de $\mathrm{Zn}^{2+}$ e $\mathrm{Mn}^{2+}$ no tecido foliar do trigo. O silicato de cálcio e magnésio proporcionou melhor equilíbrio nutricional de $\mathrm{Mn}^{2+}$ do trigo, reduzindo a quantidade excessiva absorvida.

Palavras-chave: Nutrição foliar. Si. Absorção de silício. Trigo. Triticum aestivum L.

\section{Introduction}

Grasses, including important crops such as wheat, sugarcane, maize, Brachiaria, and rice, have the ability to accumulate silicon (Si) (BARBOSA FILHO et al., 2001; SARTO et al., 2016, SARTO et al., 2014a, SARTO et al., 2014b). The degree to which different genotypes accumulate $\mathrm{Si}$ varies. The Si content can be equal to or even exceed the primary macronutrient content (EPSTEIN, 1999; RAFI et al., 1997; SARTO et al., 2015). Calcium and magnesium silicate can be used to correct soil acidity and as a source of silicon (CRUSCIOL et al., 2009; SARTO et al., 2015).

Silicon is not considered essential but is beneficial to plants. The application of Si to the soil results in the increased growth and yield of plants that accumulate $\mathrm{Si}$, such as rice (ZANÃO JÚNIOR et al., 2010), sugar cane (DEMATTÊ et al., 2011), and wheat (SARTO et al., 2015). Silicon leads to increased growth and yield through various indirect effects, such as facilitating the establishment of more erect leaves, decreasing shading, providing higher structural rigidity of the tissue, reducing lodging, and protecting against both abiotic (reduced toxicity of iron, manganese, aluminum and sodium) and biotic stresses (increased protection against pathogens and phytophagous insects) (EPSTEIN, 1994; MARSCHNER, 1995).

The deposition of Si in plant leaves contributes to improving the distribution of manganese $\left(\mathrm{Mn}^{+}\right)$within tissues and to the prevention of $\mathrm{Mn}^{+}$ toxicity. Silicon helps decrease water loss through transpiration and reduces adverse effects caused by excess nitrogen (N) (MA; TAKAHASHI, 2002). Silicon has also been found to alleviate the toxic effects of $\mathrm{Al}^{+3}$ in Brachiaria (SARTO et al., 2017). Silicate promotes the resistance of plants to salt and/or water stress, guaranteeing the integrity and stability of the cell membrane (ZUCARINI, 2008). Ruppenthal et al. (2016) found that the application of Si stimulates the defense mechanisms of soybean plants. However, the degree of stimulation is not sufficient to mitigate the negative effects of drought stress on relative water content and dry matter production.

In addition to supplying nutrients such as $\mathrm{Ca}^{+2}$, $\mathrm{Mg}^{+2}$, and $\mathrm{Si}$ to the soil (SARTO et al., 2015), silicates also interact with phosphorus (P) and NPK fertilization. Lima Filho et al. (1999) showed that the use of silicate fertilizers increases the efficiency of NPK fertilization. Silicates provide good adsorption properties and decrease the amount of potassium $\left(\mathrm{K}^{+}\right)$and other mobile nutrients that leak into the soil.

The application of silicate has beneficial effects on the development and yield of several Si-accumulating crop species such as Urochloa brizantha (SARTO et al., 2016), rice (CARVALHOPUPATTO et al., 2004), sugar cane (REIS et al., 2013), maize (CASTRO; CRUSCIOL, 2013), and wheat (SARTO et al., 2015). The beneficial effects of silicate may be related to the effects of $\mathrm{Si}$ on plants under biotic or abiotic stress, even though $\mathrm{Si}$ is not considered essential for plant growth, either physiologically or metabolically (EPSTEIN; BLOOM, 2005). The increased growth and grain 
yield of plants supplied with $\mathrm{Si}$ is associated with changes in plant architectures. These changes make plants more erect, improve the leaf angle and light interception, prevent excessive self-shading, delay senescence, increase the structural rigidity of tissues, improve photosynthesis, and reduce lodging (GONG; CHEN, 2012; MA; YAMAJI, 2008). These beneficial effects are attributed to the deposition of $\mathrm{Si}$ in the cell walls of various plant organs (MA; YAMAJI, 2006) and other mechanisms. The deposition of large amounts of Si forms a physical barrier that enhances the strength and rigidity of tissues.

The use of silicate is among the most common agricultural practices in Brazil. Therefore, an improved understanding of the effects of Si on wheat crops is essential for the adoption of management strategies that aim to improve crop production. However, there is a lack of studies on the effects of silicate on silicon utilization and nutrient uptake in wheat conducted in Brazil (SARTO et al., 2015; MAUAD et al., 2011). Thus, the purpose of this study was to investigate the effects of calcium and magnesium silicate on silicon utilization and macro- and micronutrient absorption in a wheat crop (Triticum aestivum L.) grown in soils of the state of Paraná, Brazil.

\section{Material and Methods}

\section{Study site description}

Pot experiments were performed in a greenhouse in Marechal Cândido Rondon, Paraná State, Brazil, $\left(24^{\circ} 31^{\prime} \mathrm{S}, 54^{\circ} 01^{\prime} \mathrm{W}\right.$ and $420 \mathrm{~m}$ asl), where the environmental conditions were as follows: minimum and maximum mean air temperature of 18 and $36{ }^{\circ} \mathrm{C}$, respectively and mean air relative humidity of $65 \%$.
Soils

Surface samples $(0.0-0.20 \mathrm{~m})$ from three representative soils of the western region of Paraná State were selected for Si fertilization studies (Table 1). Physical and chemical properties of the soils were determined by adopting standard procedures, and some properties are listed in Table 2. Soil $\mathrm{pH}$ in $0.01 \mathrm{~mol} \mathrm{~L}^{-1} \mathrm{CaCl}_{2}$ solution was determined potentiometrically in a 1:2.5 (soil:solution) suspension by using a combined calomel reference glass electrode and $\mathrm{pH}$ meter. Organic matter was quantified by oxidation with potassium dichromate in the presence of sulfuric acid (ROSSET et al., 2014; ROSSET et al., 2016), followed by titration with ammonium Fe(II) sulfate (EMBRAPA, 2009). Available phosphorus (P), exchangeable potassium $\left(\mathrm{K}^{+}\right)$, and cationic micronutrients $\left(\mathrm{Cu}^{+}, \mathrm{Zn}^{+}, \mathrm{Fe}^{+}\right.$, and $\mathrm{Mn}^{+}$) were extracted using Mehlich-1 solution in a 1:10 (w:v) soil-to-extractant solution ratio (EMBRAPA, 2009, SARTO et al., 2011); P was determined using colorimetry at $725 \mathrm{~nm}$ wave length and $\mathrm{K}^{+}$and micronutrients were determined using atomic absorption spectrophotometry. Calcium $\left(\mathrm{Ca}^{2+}\right)$ and magnesium $\left(\mathrm{Mg}^{2+}\right)$ were extracted by 1 mol L ${ }^{-1} \mathrm{KCl}$ solution and determined using atomic absorption spectrophotometry. Cation exchange capacity (CEC) was estimated using the summation method $\left(\mathrm{CEC}=\mathrm{H}+\mathrm{Al}^{+}+\mathrm{Ca}^{2+}+\mathrm{Mg}^{2+}+\mathrm{K}^{+}\right)$. Soluble $\mathrm{Si}$ was extracted by $0.5 \mathrm{~mol} \mathrm{~L}^{-1}$ acetic acid solution in a 1:10 (w:v) soil-to-extractant solution ratio (KORNDÖRFER et al., 1999a) and determined by beta molybdosilicic complex formation with a spectrophotometer at $660 \mathrm{~nm}$ wave length. Particle size analysis was performed using the pipette method (EMBRAPA, 2009), according to decantation speed of different soil particles after dispersion in $0.015 \mathrm{~mol} \mathrm{~L}^{-1}\left(\mathrm{NaPO}_{3}\right) 6 . \mathrm{NaO} / 1.0 \mathrm{~mol}$ $\mathrm{L}^{-1} \mathrm{NaOH}$ by overnight shaking. 
Table 1. Brazilian soil classification, approximate equivalence to soil taxonomy and sampling site of the three soils from Paraná State, Brazil.

\begin{tabular}{lcc}
\hline Brazilian soil classification $^{\dagger}$ & Soil taxonomy & Soil \\
\hline Eutroferric Red Latosol & Rhodic Acrudox & Ox1 \\
Distroferric Red Latosol & Rhodic Hapludox & Ox2 \\
Red-Yellow Argisol & Arenic Hapludult & Ult \\
\hline
\end{tabular}

${ }^{\dagger}$ According to Embrapa (2013). ${ }^{\dagger}$ USDA Soil Taxonomy (Soil Survey Staff, 2010).

Table 2. Some physical and chemical properties of the soils.

\begin{tabular}{lccc}
\hline \multirow{2}{*}{ Soil characteristics } & \multicolumn{3}{c}{ Soil } \\
\cline { 2 - 4 } & Acrudox & Hapludox & Hapludult \\
\hline Soil $\mathrm{pH}$ & 5.3 & 4.1 & 6.2 \\
Clay $\left(\mathrm{g} \mathrm{kg}^{-1}\right)$ & 550.0 & 535.0 & 100.0 \\
Silt $\left(\mathrm{g} \mathrm{kg}^{-1}\right)$ & 370.0 & 430.0 & 45.0 \\
Sand $\left(\mathrm{g} \mathrm{kg}^{-1}\right)$ & 80.0 & 35.0 & 855.0 \\
Organic matter $\left(\mathrm{g} \mathrm{kg}^{-1}\right)$ & 26.0 & 39.6 & 22.0 \\
Available P $\left(\mathrm{mg} \mathrm{kg}^{-1}\right)$ & 37.1 & 22.5 & 40.7 \\
$\mathrm{H}+\mathrm{Al}\left(\mathrm{cmol}_{\mathrm{c}} \mathrm{kg}^{-1}\right)$ & 4.6 & 10.7 & 2.0 \\
Exchangeable Al $\left(\mathrm{cmol}_{\mathrm{c}} \mathrm{kg}^{-1}\right)$ & 0.0 & 2.4 & 0.0 \\
Exchangeable K $\left(\mathrm{cmol}_{\mathrm{c}} \mathrm{kg}^{-1}\right)$ & 0.15 & 0.20 & 0.20 \\
Calcium $\left(\mathrm{cmol}_{\mathrm{c}} \mathrm{kg}^{-1}\right)$ & 4.8 & 4.0 & 2.5 \\
Magnesium $\left(\mathrm{cmol}_{\mathrm{c}} \mathrm{kg}^{-1}\right)$ & 1.8 & 0.5 & 0.7 \\
CEC $\left(\mathrm{cmol}_{\mathrm{c} \mathrm{kg}^{-1}}^{\dagger}\right.$ & 11.4 & 15.4 & 5.4 \\
Soil base saturation $(\%)$ & 60.0 & 30.0 & 63.0 \\
Copper $\left(\mathrm{mg} \mathrm{kg}^{-1}\right)$ & 15.0 & 8.2 & 9.9 \\
Zinc $\left(\mathrm{mg} \mathrm{kg}^{-1}\right)$ & 132.0 & 110.0 & 247.0 \\
Iron $\left(\mathrm{mg} \mathrm{kg}^{-1}\right)$ & 41.1 & 35.4 & 28.5 \\
Manganese $\left(\mathrm{mg} \mathrm{kg}^{-1}\right)$ & 3.9 & 8.2 & 5.4 \\
Silicon $\left(\mathrm{mg} \mathrm{kg}^{-1}\right)$ & 19.3 & 15.8 & 18.0 \\
\hline
\end{tabular}

${ }^{\dagger}$ CEC: cation exchange capacity.

\section{Experimental design and treatments}

The experimental design was a $3 \times 5$ factorial in complete randomized blocks, with four replications. Treatments consisted of three soils- Ox1, Ox2, and Ult — and wheat plants grown using 0 (control), 1, 2, 4 , and $6 \mathrm{tha}^{-1}$ of $\mathrm{CaSiO}_{3} / \mathrm{MgSiO}_{3}$. The silicate source used was AgroSilício ${ }^{\circledR}(10.5 \% \mathrm{Si}, 25 \% \mathrm{Ca}, 6 \% \mathrm{Mg}$, and $88 \%$ effective calcium carbonate equivalent (ECCE). The corrected soils were maintained for 15 days with water content at $60 \%$ field capacity.
Then, the soils were placed in 8 - $\mathrm{L}$ plastic pots and fertilized by applying $30 \mathrm{mg} \mathrm{kg}^{-1}$ of $\mathrm{N}$ (urea), $80 \mathrm{mg}$ $\mathrm{kg}^{-1}$ of $\mathrm{P}$ (simple superphosphate), and $60 \mathrm{mg} \mathrm{kg}^{-1}$ of $\mathrm{K}(\mathrm{KCl})$.

\section{Plant material}

Five seeds of the wheat (Triticum aestivum L., cv. BRS Pardela) were sown, and nine days after seedling emergence, they were thinned to three 
plants per pot. The pots were irrigated daily to maintain soil moisture near at near field capacity. We sowed five wheat seeds per pot (variety: BRS Pardela). After nine days, we carried out the thinning process, leaving three plants per pot. The pots were watered daily in order to keep the soil moisture close to its field capacity. At 30 days after plant emergence, the application of $45 \mathrm{mg} \mathrm{kg}^{-1} \mathrm{~N}$ as urea a solution was also performed.

\section{Silicon absorption and nutrition of wheat}

At flowering, the plants were separated into leaves and stems, dried in a forced air circulation oven for three days at $65 \pm 2^{\circ} \mathrm{C}$, ground in a Willyetype mill and then subjected to 3:1 nitric-perchloric acid digestion. The concentrations of $\mathrm{K}^{+}, \mathrm{Ca}^{2+}, \mathrm{Mg}^{2+}$, $\mathrm{S}, \mathrm{Cu}^{2+}, \mathrm{Fe}^{2+}, \mathrm{Mn}^{2+}$ and $\mathrm{Zn}^{2+}$ in leaf were determined by flame atomic absorption spectrometry (FlameAAS). Phosphorus was determined by colorimetry, Nitrogen by sulfuric acid digestion and steam drag distillation (EMBRAPA, 2009), and Si by digestion with hydrogen peroxide as well as sodium hydroxide and subsequently by colorimetry (KORNDÖRFER et al., 2004).

The level of silicon absorbed by the plants from the fertilizer was obtained by the difference between the silicon accumulated in the plant shoot and the silicon accumulated by the control treatment. The average recovery of silicon by plants was obtained by the division of the silicon absorbed from the fertilizer by the silicon applied x 100 (KORNDÖRFER et al., 1999).

\section{Statistical analysis}

Original data were analyzed using analysis of variance and regression analysis, and significant equations with the highest coefficients of determination (Tukey test, $\mathrm{p} \leq 0.05$ ) were adjusted.
All analyses were performed using Saeg (1999) 8.0 software for Windows (Statistical Analysis Software, UFV, Viçosa, MG, BRA).

\section{Results and Discussion}

\section{Silicon absorption by wheat}

The application of calcium and magnesium silicate to the soil resulted in a significant increase in $\mathrm{Si}$ concentrations within wheat leaves and stems (Figure 1). When the application rate of silicate was increased from 0 to $6 \mathrm{tha}^{-1}$, the silicon content within leaves increased from 27 to $36.4(\mathrm{Ox} 1), 21.3$ to 49 (Ult), and 22.6 to 33.5 (Ox2) $\mathrm{g} \mathrm{kg}^{-1}$ (Figure 1A). In plants grown in Ult soil, the concentration of Si was higher in leaves (approximately $49 \mathrm{~g}$ $\mathrm{kg}^{-1}$ ) than in stems (approximately $20 \mathrm{~g} \mathrm{~kg}^{-1}$ ). The increased concentration of $\mathrm{Si}$ in the shoots indicates that the silicate we used was reactive and effective in providing $\mathrm{Si}$ to the soil and the plant.

Korndörfer et al. (2010) conducted a study evaluating the effects of the surface application of calcium silicate $\left(\mathrm{CaSiO}_{3}\right.$; maximum rate: $\left.2 \mathrm{t} \mathrm{ha}^{-1}\right)$ on $\mathrm{Si}$ concentrations in grass shoots. They reported that the Si concentration within the leaves of grass grown in soil treated with calcium silicate was twice that of grass grown in the control soil (no silicate). According to the authors, an increase in the concentration of $\mathrm{Si}$ in the shoots would indicate that the calcium silicate is reactive and efficient in providing Si to the soil and the plant.

Lima Filho and Tsai (2007) observed exponential silicon absorption in three cultivars of wheat and two cultivars of oat when adding Si to the nutrient solution at doses of up to $100 \mathrm{mg} \mathrm{L}^{-1}$. The authors concluded that both grasses (wheat and oat) have high silicon uptake capacities, suggesting that large quantities of silicon can be absorbed when the availability of the element is increased in the substrate. 
Figure 1. Effect of calcium and magnesium silicate rates on the content of silicon in the leaf (A) and stem (B) of wheat plants. ** Significant at $1 \%, *$ Significant at $5 \%$, and ns: non-significant by the $\mathrm{F}$ test.
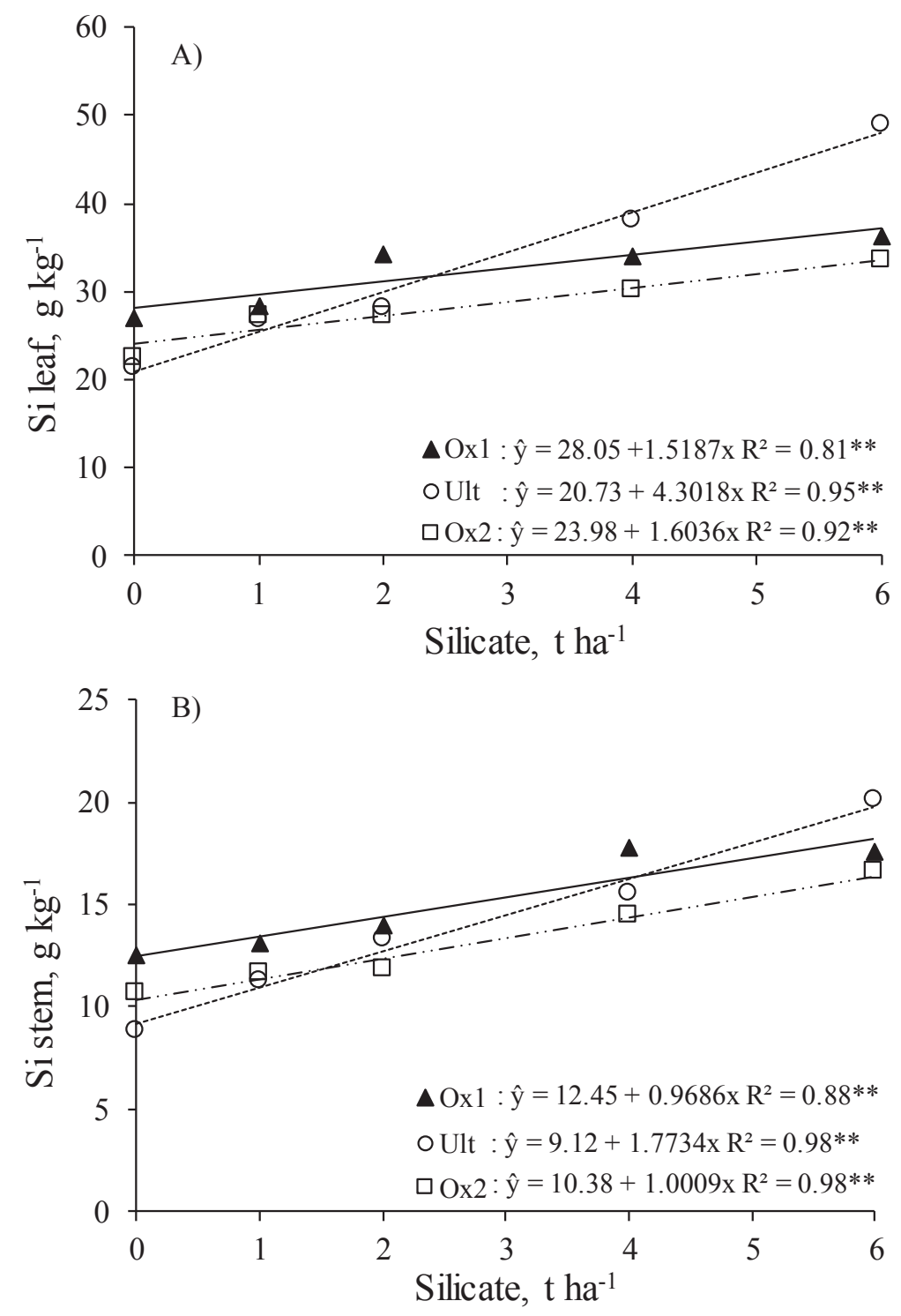

Sarto et al. (2016) investigated whether the application of $\mathrm{CaSiO}_{3}$ increases the $\mathrm{Si}$ content in Brachiaria and interferes with gas exchange and production components. They found that applying $\mathrm{CaSiO}_{3}$ to the soil increases $\mathrm{Si}$ concentration in the leaves. Additionally, they found that Sireduces internal $\mathrm{CO}_{2}$ concentrations and increases the efficiency of water use and instantaneous carboxylation efficiency. In soils with low $\mathrm{pH}$ and high levels of $\mathrm{Al}^{+3}, \mathrm{Si}$ helps alleviate the toxic effects of $\mathrm{Al}^{+3}$ by reducing sweating in Brachiaria, which in turn increases water use efficiency (SARTO et al., 2016).
In this study, we observed an increase in the silicon content within stems from 12.5 to 17.5 , 8.8 to 20 , and 10.6 to $16.5 \mathrm{~g} \mathrm{~kg}^{-1}$ in plants grown in Ox1, Ult, and Ox2 soils, respectively (Figure 1B). Silicon deposition in the stem may promote increased resistance to lodging, which is an important feature for the mechanical harvesting of wheat. The selection of varieties with high $\mathrm{Si}$ absorption potential can minimize damping-off problems, reducing mechanical harvesting losses (MA; TAKAHASHI, 2002). 


\section{Average recovery of silicon}

We found average silicon recovery rates of $28.20 \%, 60.61 \%$, and $74.14 \%$ in wheat grown in Ox1, Ult, and Ox2, respectively (Table 3). Depending on the silicate application rates, $\mathrm{Si}$ recovery rates ranged from $19.68 \%$ to $48.38 \%$ in Ox1, $47.77 \%$ to $78.68 \%$ in Ult, and $42.08 \%$ to $128.27 \%$ in Ox2. Plants grown in Ult and Ox2 soils had higher Si recovery rates $(60.61 \%$ and $74.14 \%$, respectively). Therefore, more than half of the total $\mathrm{Si}$ absorbed by plants grown in Ult and $\mathrm{Ox} 2$ came from the silicate fertilizer.

Table 3. Silicon content available in the soil, Si accumulated in the wheat shoots, Si absorbed from the fertilizer and recovery rate, as a function of the calcium and magnesium silicate rates.

\begin{tabular}{|c|c|c|c|c|c|}
\hline $\mathrm{Si}$ & Si "'available" & Si accumulated & Si absorbed from & Recovery & \\
\hline \multirow[t]{3}{*}{ applied } & in soil & in leaves & the fertilizer * & rate** & Mean \\
\hline & & $-\mathrm{g} / \mathrm{pot}$ & $\bar{z}$ & \multicolumn{2}{|c|}{$\%$} \\
\hline & \multicolumn{3}{|c|}{ Ox1 } & & \\
\hline 0 & 0.24 & 1.523 & - & - & \multirow{5}{*}{28.20} \\
\hline 0.42 & 0.28 & 1.605 & 0.083 & 19.68 & \\
\hline 0.84 & 0.33 & 1.929 & 0.406 & 48.38 & \\
\hline 1.68 & 0.42 & 1.920 & 0.397 & 23.62 & \\
\hline 2.52 & 0.53 & 2.055 & 0.532 & 21.12 & \\
\hline \multicolumn{6}{|c|}{ Ult } \\
\hline 0 & 0.23 & 1.299 & - & - & \multirow{5}{*}{60.61} \\
\hline 0.42 & 0.24 & 1.629 & 0.330 & 78.68 & \\
\hline 0.84 & 0.27 & 1.711 & 0.412 & 49.05 & \\
\hline 1.68 & 0.32 & 2.101 & 0.803 & 47.77 & \\
\hline 2.52 & 0.39 & 2.985 & 1.687 & 66.93 & \\
\hline \multicolumn{6}{|c|}{ Ox2 } \\
\hline 0 & 0.20 & 0.893 & - & - & \multirow{5}{*}{74.14} \\
\hline 0.42 & 0.20 & 1.432 & 0.539 & 128.27 & \\
\hline 0.84 & 0.23 & 1.498 & 0.605 & 72.04 & \\
\hline 1.68 & 0.29 & 1.803 & 0.910 & 54.15 & \\
\hline 2.52 & 0.31 & 1.95 & 1.060 & 42.08 & \\
\hline
\end{tabular}

$* \mathrm{Si}$ absorbed from the fertilizer $=\mathrm{Si}$ accumulated in the shoots $-\mathrm{Si}$ accumulated by the control treatment; **Recovery rate $(\%)=$ (Si absorbed from the fertilizer / Si applied) x 100 (Korndörfer et al., 1999).

In a study on the effects of using calcium silicate as a source of Si for cultivating upland rice in four soils representing the Cerrado region (Brazil), Korndörfer et al. (1999) found that Si recovery was increased in soils with higher clay content. Clayey soils contain higher amounts of phyllosilicates (clay minerals that release $\mathrm{Si}^{4+}$ and $\mathrm{Al}^{3+}$ ) and higher amounts of $\mathrm{Si}$ in solution than sandy soils. Although sandy soils are rich in quartz $\left(\mathrm{SiO}_{2}\right)$, they are not a good source of
Si because the chemical decomposition of quartz is difficult (DEMATTÊ et al., 2011).

In this study, we observed higher average $\mathrm{Si}$ recovery rates in one of the clayey soils $(74.14 \%$ in Ox2) than in the sandy soil (60.61\% in Ult), but lower Si recovery rates in the other clayey soil $(28.20 \%$ in Ox1). The relatively high Si recovery rate in the sandy Ult soil may be explained by the conditions 
in which the experiment was conducted. The plants were watered daily, resulting in increased interaction between silicate particles and the solid phase of the soil. This, in turn, led to highly reactive silicate soils. According to Souza et al. (2008), soils with low levels of clay, organic matter, and water retention capacity show decreased interaction between silicate particles and the solid phase of the soil.

\section{Nutritional mineral contents in wheat}

The concentrations of the nutrients $\mathrm{N}, \mathrm{P}, \mathrm{S}$, $\mathrm{Cu}^{2+}$, and $\mathrm{Fe}^{2+}$ were not affected by the application of silicate to the soil (Table 4). These results were similar to those reported by Prado et al. (2002a), who studied the effects of applying limestone and steel slag at different rates on the absorption of nutrients in sugarcane plants. The authors found no effects on the concentrations of $\mathrm{N}, \mathrm{P}, \mathrm{K}^{+}, \mathrm{Ca}^{+2}, \mathrm{Mg}^{+2}$, and $\mathrm{S}$ in the plants. In this experiment, the concentrations of most nutrients measured within the leaves are in the range classified as medium and are suitable for the crop (EMBRAPA, 2009; RAIJ, 2011). However, $\mathrm{N}$ and $\mathrm{S}$ concentrations were below the adequate range, and $\mathrm{Fe}^{2+}$ and $\mathrm{Mn}^{2+}$ concentrations were above the adequate range.

Our results were also similar to those reported by Sarto et al. (2014a), who investigated the nutrition of wheat as a function of silicate fertilization. They observed that the concentrations of $\mathrm{N}, \mathrm{P}, \mathrm{Mg}^{+2}, \mathrm{~S}$, $\mathrm{Cu}^{2+}$, and $\mathrm{Fe}^{2+}$ in wheat flag leaves were not affected by the application of calcium silicate to the soil.

Table 4. Average values of macro and micronutrients in the wheat leaf as a function of the increasing rates of calcium and magnesium silicate.

\begin{tabular}{|c|c|c|c|c|c|c|c|c|c|c|}
\hline Silicate & $\mathrm{N}$ & $\mathrm{P}$ & $\mathrm{K}$ & $\mathrm{Ca}$ & $\mathrm{Mg}$ & $\mathrm{S}$ & $\mathrm{Cu}$ & $\mathrm{Zn}$ & $\mathrm{Fe}$ & $\mathrm{Mn}$ \\
\hline \multirow[t]{2}{*}{$\mathrm{t} \mathrm{ha}^{-1}$} & & 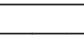 & $\mathrm{g}$ & -1 & & & & $\mathrm{~m}$ & $\mathrm{~g}^{-1}$ & \\
\hline & \multicolumn{10}{|c|}{ Ox 1} \\
\hline 0 & 18.68 & 2.54 & 22.45 & 12.36 & 3.03 & 1.19 & 8.9 & 37.5 & 609.3 & 288.0 \\
\hline 1 & 15.41 & 2.67 & 23.04 & 13.79 & 3.68 & 1.17 & 9.4 & 25.9 & 708.8 & 202.3 \\
\hline 2 & 15.30 & 2.54 & 23.62 & 12.96 & 3.84 & 1.20 & 7.2 & 20.3 & 787.0 & 180.5 \\
\hline 4 & 19.70 & 2.45 & 22.83 & 15.63 & 4.11 & 1.20 & 4.2 & 18.0 & 688.5 & 169.5 \\
\hline 6 & 21.80 & 2.25 & 21.69 & 16.10 & 4.68 & 1.18 & 7.2 & 11.2 & 663.9 & 140.1 \\
\hline \multirow[t]{2}{*}{ Regression } & ns & $\mathrm{ns}$ & ns & $\mathrm{L}^{*}$ & $\mathrm{~L}^{* *}$ & ns & ns & $\mathrm{L}^{* *}$ & ns & $\mathrm{L}^{* *}$ \\
\hline & \multicolumn{10}{|c|}{ Ult } \\
\hline 0 & 20.22 & 3.17 & 23.84 & 12.84 & 3.44 & 1.10 & 3.0 & 34.8 & 515.7 & 64.8 \\
\hline 1 & 15.94 & 2.85 & 25.43 & 12.98 & 4.05 & 1.10 & 4.1 & 31.7 & 476.6 & 57.8 \\
\hline 2 & 17.15 & 3.06 & 24.32 & 13.05 & 4.37 & 1.13 & 6.6 & 24.0 & 423.2 & 50.0 \\
\hline 4 & 19.93 & 3.44 & 26.25 & 13.92 & 4.87 & 1.11 & 5.3 & 20.5 & 435.2 & 58.7 \\
\hline 6 & 18.44 & 2.57 & 23.88 & 14.51 & 5.94 & 1.09 & 5.6 & 17.8 & 482.5 & 51.5 \\
\hline \multirow[t]{2}{*}{ Regression } & ns & ns & ns & $\mathrm{L}^{*}$ & $\mathrm{~L}^{* *}$ & $\mathrm{~ns}$ & $\mathrm{~ns}$ & $\mathrm{~L}^{* *}$ & ns & $\mathrm{ns}$ \\
\hline & \multicolumn{10}{|c|}{ Ox2 } \\
\hline 0 & 22.21 & 2.61 & 33.61 & 8.53 & 2.57 & 1.13 & 6.1 & 62.1 & 482.2 & 591.5 \\
\hline 1 & 22.23 & 1.97 & 30.39 & 10.01 & 2.84 & 1.14 & 7.1 & 41.7 & 448.7 & 486.1 \\
\hline 2 & 20.90 & 2.00 & 27.93 & 11.09 & 2.78 & 1.12 & 5.1 & 29.3 & 455.0 & 437.4 \\
\hline 4 & 27.19 & 2.30 & 28.13 & 11.23 & 3.26 & 1.16 & 7.7 & 26.4 & 435.2 & 273.1 \\
\hline 6 & 23.05 & 2.03 & 27.10 & 13.10 & 4.25 & 1.18 & 4.2 & 22.1 & 370.8 & 227.1 \\
\hline Regression & ns & $\mathrm{ns}$ & $\mathrm{L}^{* *}$ & $\mathrm{~L}^{* *}$ & $\mathrm{~L}^{* *}$ & $\mathrm{~ns}$ & $\mathrm{~ns}$ & $\mathrm{~L}^{* *}$ & ns & $\mathrm{L}^{* *}$ \\
\hline
\end{tabular}

* Significant at $5 \%$ and $* *$ significant at $1 \%$ by the $\mathrm{F}$ test. ${ }^{\text {ns }}$ non-significant at $5 \%$ by the $\mathrm{F}$ test. L: Linear. 
The adequate range for $\mathrm{N}$ concentrations in plants is between 20 and $34 \mathrm{~g} \mathrm{~kg}^{-1}$ (MALAVOLTA et al., 1997). In this study, plants grown in Ox1, Ult, and Ox2 soils showed average levels of 18.18, 18.34 and $23.12 \mathrm{mg} \mathrm{kg}^{-1}$, respectively. The adequate range for $\mathrm{S}$ in plants is between 1.5 and $3.0 \mathrm{~g} \mathrm{~kg}^{-1}$ (MALAVOLTA et al., 1997). In our experiment, plants showed mean values of $1.19,1.11$ and $1.15 \mathrm{~g}$ $\mathrm{kg}^{-1}$ in Ox1, Ult, and Ox2 soils, respectively.

A linear model revealed that the content of $\mathrm{K}^{+}$ in leaves of plants grown in Ox2 soil decreased significantly with increasing rates of silicate application (Figure 2). According to Malavolta et al. (1997), cations $\mathrm{K}^{+}$and $\mathrm{Ca}^{2+}$ cations compete for the same absorption sites within plant roots. The reduction in $\mathrm{K}^{+}$content in the shoots of wheat grown in $\mathrm{Ox} 2$ soil may be due to $\mathrm{K}^{+}$competing with calcium connected to silicate within the calcium and magnesium silicate $\left(\mathrm{CaSiO}_{3} / \mathrm{MgSiO}_{3}\right)$ that we applied to the soil. Similarly, Sarto et al. (2014a) and Soratto et al. (2012) found that the application of silicon to wheat leaves increased the $\mathrm{K}^{+}$concentration within flag leaves.

Figure 2. Effect of calcium and magnesium silicate rates on the $\mathrm{K}$ content of wheat leaf. * Significant at $5 \%$ and $* *$ significant at $1 \%$ by the $\mathrm{F}$ test. ${ }^{\mathrm{ns}}$ non-significant at $5 \%$ by the $\mathrm{F}$ test.

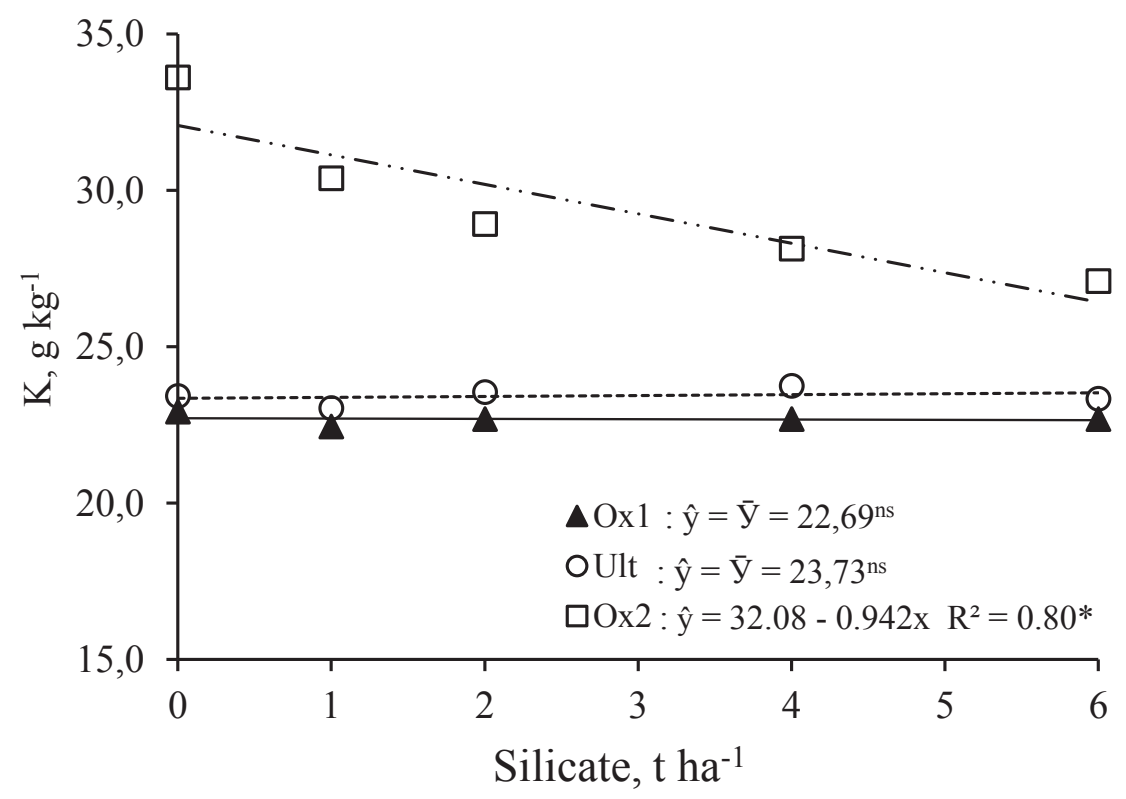

Prado et al. (2003) evaluated the residual effects of steel slag on a yellow Oxisol cultivated with sugarcane and observed an increase in $\mathrm{Ca}^{2+}$ and $\mathrm{Mg}^{2+}$ concentrations at a depth of $0-0.2 \mathrm{~m}$. The increase in $\mathrm{Ca} 2+$ and $\mathrm{Mg} 2+$ observed in our study (Figure 3) may have resulted from the chemical composition of the fertilizer that we used. The greater availability of these nutrients for the plants from the calcium and magnesium silicate may explain the increased concentration of calcium and magnesium in wheat leaves (SARTO et al., 2015). Prado et al. (2002b) also observed an increase in the absorption of calcium and magnesium in the shoots of lettuce plants as a result of the application of steel slag, magnesium, and dolomitic limestone to an Oxisol. The authors reported that the correctors they used are a source of $\mathrm{Ca}^{2+}$ and $\mathrm{Mg}^{2+}$, elevating the $\mathrm{Ca}^{2+}$ and $\mathrm{Mg}^{2+}$ concentrations in the soil. This, in turn, influences the levels of these nutrients within plant shoot. 
Figure 3. Effect of the rates of calcium and magnesium silicate on the content of $\mathrm{Ca}(\mathrm{A})$ and $\mathrm{Mg}(\mathrm{B})$ in the wheat leaf.

* Significant at $5 \%$ and $* *$ significant at $1 \%$ by the $\mathrm{F}$ test. ${ }^{\text {ns }}$ non-significant at $5 \%$ by the $\mathrm{F}$ test.
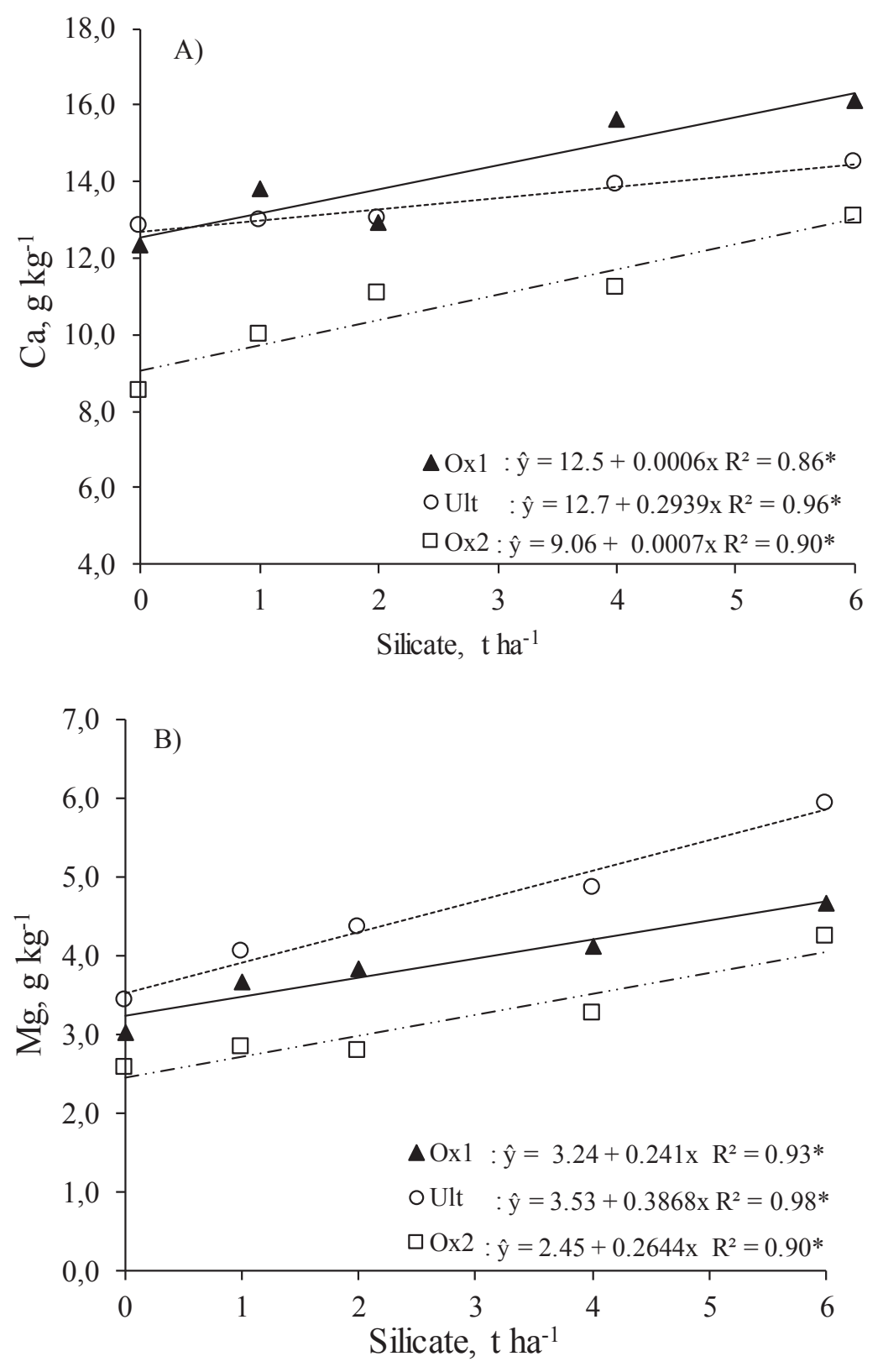

There were significant differences between $\mathrm{Cu}^{2+}$, $\mathrm{Zn}^{2+}, \mathrm{Fe}^{2+}$, and $\mathrm{Mn}^{2+}$ concentrations in the leaves (Table 4). The $\mathrm{Zn}^{2+}$ and $\mathrm{Mn}^{2+}$ values decreased with increasing silicate application rates (Figure 4). These results are similar to those obtained by Moraes et al. (2009), when assessing the effects of calcium silicate and copper sulfate on nutrient contents in beans, the authors observed that increasing calcium silicate rates had no significant effect on the concentration of $\mathrm{Cu}^{2+}, \mathrm{Fe}^{2+}$, and $\mathrm{Mn}^{2+}$ within shoots. However, increasing calcium silicate rates led to a reduction in $\mathrm{Zn}^{2+}$. Increasing calcium silicate rates may lead to lower concentrations of $\mathrm{Zn}^{2+}$ and $\mathrm{Mn}^{2+}$ in wheat leaves because silicate use reduces the soil pH (SARTO et al., 2015). A reduced $\mathrm{pH}$, in turn, reduces the bioavailability of these micronutrients in the soil. 
Figure 4. Effect of the rates of calcium and magnesium silicate on the content of $\mathrm{Zn}(\mathrm{A})$ and $\mathrm{Mn}(\mathrm{B})$ in wheat leaf. * Significant at $5 \%$ and $* *$ significant at $1 \%$ by the $\mathrm{F}$ test. ns non-significant at $5 \%$ by the $\mathrm{F}$ test.
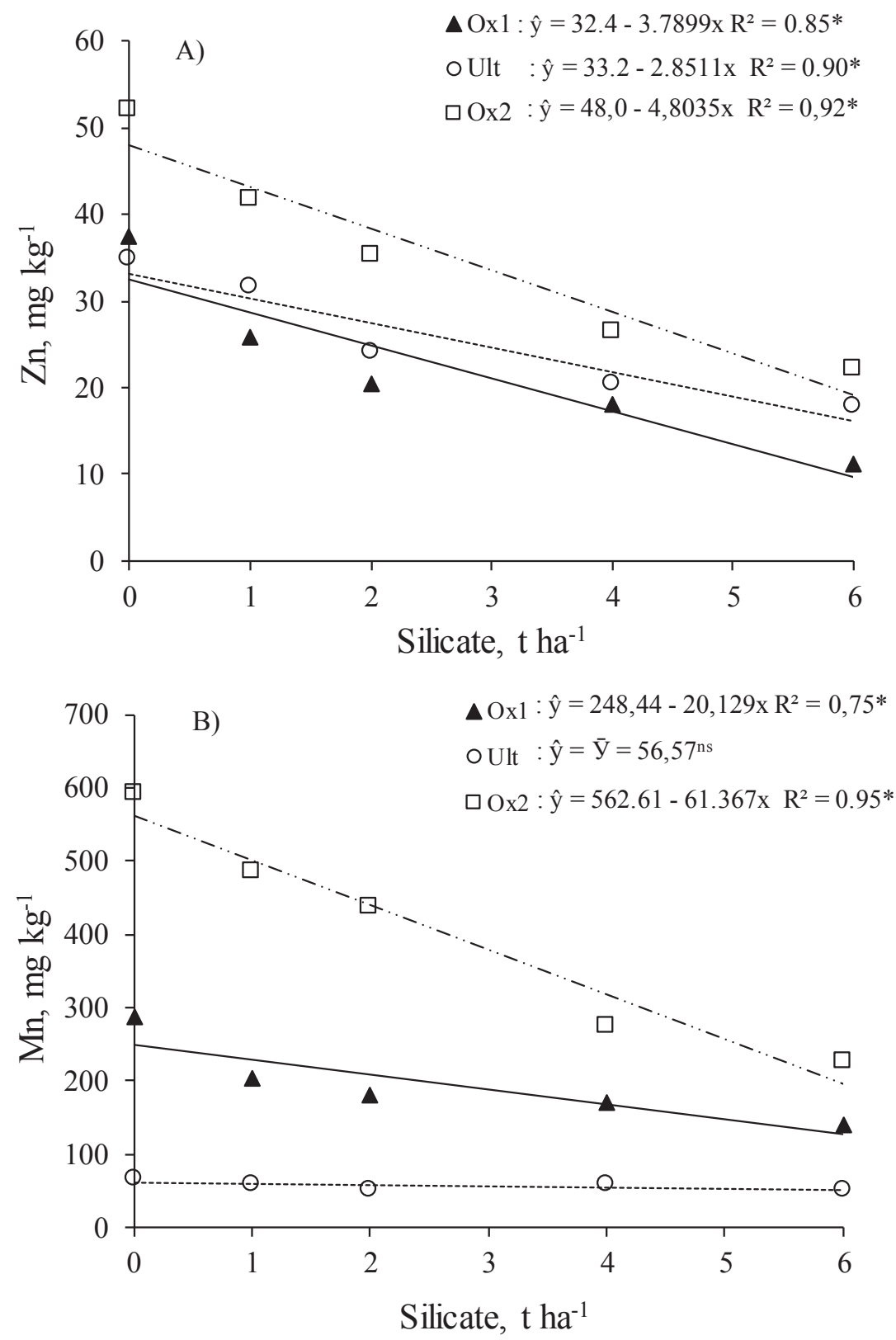

The concentrations of $\mathrm{Fe}^{2+}$ and $\mathrm{Mn}^{2+}$ were above the adequate range for wheat crops. According to Embrapa (2009) and Raij (2011), the adequate range for $\mathrm{Fe}^{2+}$ is between 10 and $300 \mathrm{mg} \mathrm{kg}^{-1}$. In our study, plants grown in Ox1, Ult, and Ox2 soils showed average Fe concentrations of $691.5,466.7$ and $438.37 \mathrm{mg} \mathrm{kg}^{-1}$, respectively. The adequate range for $\mathrm{Mn}^{2+}$ is between 25 and $150 \mathrm{mg} \mathrm{kg}^{-1}$
(EMBRAPA, 2009; RAIJ, 2011). In our study, plants grown in $\mathrm{Ox} 1$ and $\mathrm{Ox} 2$ soils showed average Fe concentrations of 196.11 (Ox1) and 403.06 (Ox2) $\mathrm{mg} \mathrm{kg}^{-1}$.

The calcium and magnesium silicate provided a better balance in the absorption of $\mathrm{Mn}^{2+}$ by wheat, reducing the amount of excessive $\mathrm{Mn}^{2+}$ absorbed by the plant (Table 4). According to Pozza et al. (2009), 
fertilizing rice plants with $\mathrm{Si}$ leads to increased oxidation of $\mathrm{Fe}^{2+}$ and $\mathrm{Mn}^{2+}$ on the root surface. Consequently, these nutrients precipitate and are not absorbed by the plant. The deposition of Si in plant leaves helps to improve the distribution of $\mathrm{Mn}^{2+}$ and prevent the toxic effects of $\mathrm{Mn}^{2+}$ within tissues (MA; TAKAHASHI, 2002).

The concentrations of $\mathrm{Zn}^{2+}$ within leaves were reduced from 37.5 to $11.17(\mathrm{Ox} 1), 34.8$ to 17.85 (Ult), and 48.12 to $22.07(\mathrm{Ox} 2) \mathrm{mg} \mathrm{kg}^{-1}$ when increasing calcium silicate rates from 0 to $6 \mathrm{t} \mathrm{ha}^{-1}$ (Figure 4A). This reduction in leaf $\mathrm{Zn}^{2+}$ concentrations may have occurred because this nutrient is reduced in the presence of calcium silicate, which leads to competitive inhibition for the absorption of nutrients (MALAVOLTA et al., 1997). The concentrations of $\mathrm{Mn}^{2+}$ within leaves were reduced from 248.1 to 120.17 (Ox1) and 562.12 to 232.44 (Ox2) $\mathrm{mg} \mathrm{kg}^{-1}$ when increasing calcium silicate rates from 0 to 6 $\mathrm{t} \mathrm{ha}^{-1}$ (Figure 4B). Lima Filho and Tsai (2007) also observed decreases in $\mathrm{Mn}^{2+}$ and $\mathrm{Zn}^{2+}$ concentrations in wheat when supplying a nutrient solution containing Si. They attributed these decreases to the fact that dry matter accumulation increased faster than nutrient accumulation, resulting in a dilution effect for most nutrients studied.

Sarto et al. (2014a) investigated the effects of the application of calcium silicate on the nutrition and yield of wheat. They also observed a reduction in leaf $\mathrm{Zn}^{2+}$ and $\mathrm{Mn}^{2+}$ concentrations (reducing concentrations by $29 \%$ and $68 \%$, respectively) when increasing calcium silicate rates from 0 (control) to $9.6 \mathrm{mg} \mathrm{ha}^{-1}$. The decrease in leaf $\mathrm{Zn}^{2+}$ and $\mathrm{Mn}^{2+}$ concentrations with increasing calcium silicate rates may have occurred because the silicate they used reduced the soil pH (SARTO et al., 2015), thereby reducing the bioavailability of these micronutrients in the soil.

Zanão Júnior et al. (2010) studied rice grown in nutrient solutions with different rates of $\mathrm{Mn}^{2+}$ and Si. They observed an increase in the dry matter production of roots, petioles, and leaves with increasing Si. The authors also showed a reduction in the amount of $\mathrm{Mn}^{2+}$ translocated to the leaves when adding $\mathrm{Si}$ to the nutrient solution. Thus, adding Si to the nutrient solution helped reduce the negative effects of excess $\mathrm{Mn}^{2+}$ in the plants. Similarly, Horst and Marschner (1978) observed that the supplementation of $0.75 \mathrm{mg} \mathrm{kg}^{-1}$ soluble silicon (Aerosil) leads to a reduction of $\mathrm{Mn}^{2+}$ levels in bean plants.

\section{Conclusions}

Silicon concentrations in wheat leaves and stems increased with increasing rates of calcium and magnesium silicate applied to the soil.

The rates of silicon recovered from the silicate were $28.2 \%, 60.61 \%$, and $74.14 \%$ in plants grown in Ox1, Ult, and Ox2 soils, respectively.

The application of calcium and magnesium silicate led to a decrease in the absorption of $\mathrm{Zn}^{2+}$ and $\mathrm{Mn}^{2+}$ in $\mathrm{Ox} 1$, Ult, and $\mathrm{Ox} 2$ soils and $\mathrm{K}^{+}$in $\mathrm{Ox} 2$ soil. It also led to an increase in the absorption of $\mathrm{Ca}^{2+}$ and $\mathrm{Mg}^{2+}$ in wheat leaves in Ox1, Ult, and $\mathrm{Ox} 2$ soils.

The calcium and magnesium silicate reduced the amount of excess $\mathrm{Mn}^{2+}$ absorbed by the wheat, improving the nutritional balance in this plant.

\section{Acknowledgments}

To CAPES (Coordination for the Improvement of Higher Education Personnel), for financial support and providing scholarship to the first author. To CNPq (National Council for Scientific and Technological Development), for an award for excellence in research to the second author.

\section{References}

BARBOSA FILHO, M. P.; SNYDER, G. H.; FAGERIA, N. K.; DATNOFF, L. E.; SILVA, O. F. Silicato de cálcio como fonte de silício para o arroz de sequeiro. Revista Brasileira de Ciência do Solo, Viçosa, v. 25, p. 325-30, 2001. 
CARVALHO-PUPATTO, J. G.; BÜLL, L. T.; CRUSCIOL, C. A. C. Atributos químicos do solo, crescimento radicular e produtividade do arroz de acordo com a aplicação de escórias. Pesquisa Agropecuária Brasileira, Brasília, v. 39, n. 12, p. 1213-1218, 2004.

CASTRO, G. S. A.; CRUSCIOL, C. A. C. Effects of superficial liming and silicate application on soil fertility and crop yield under rotation. Geoderma, Amsterdam, v. 195-196, p. 234-242, 2013.

CRUSCIOL, C. A. C.; PULZ, A. L.; LEMOS, L. B.; SORATTO, R. P.; LIMA, G. P. P. Effects of silicon and drought stress on tuber yield and leaf biochemical characteristics in potato. Crop Science, Madison, v. 49, n. 3, p. 949-954, 2009.

DEMATTÊ, J. L. I.; PAGIARO, C. M.; BELTRAME, J. A.; RIBEIRO, S. S. Uso de silicatos em cana-de-açúcar. Informações Agronômicas, v. 133, p. 7-12, 2011.

EMPRESA BRASILEIRA DE PESQUISA AGROPECUÁRIA - EMBRAPA. Centro Nacional de Pesquisa de Solos. Sistema brasileiro de classificação de solos. 3. ed. Rio de Janeiro: Embrapa Solos, 2013. 353 p.

Manual de análises químicas de solos, plantas e fertilizantes. 2. ed. Brasília: Informação Tecnológica, 2009. $628 \mathrm{p}$.

EPSTEIN, E. A. Anomalia de silício em biologia vegetal. Proceedings of National Academy of United States of America, Washington, v. 91, p. 11-17, 1994.

EPSTEIN, E. Silicon. Annual Review of Plant Physiology and Plant Molecular Biology, Palo Alto v. 50, p. 641664, 1999.

EPSTEIN, E.; BLOOM, A. J. Mineral nutrition of plants: principles and perspectives. Sunderland: Sinauer Associates, 2005. 400 p.

GONG, H.; CHEN, K. The regulatory role of silicon on water relations, photosynthetic gas exchange, and carboxylation activities of wheat leaves in field drought conditions. Acta Physiology Plant, v. 34, n. 4, p. 1-6, 2012.

HORST, W. J.; MARSCHNER, H. Effect of silicon on manganese tolerance of bean plants (Phaseolus vulgaris L.). Plant and Soil, v. 50, n. 1-3, p. 287-303, 1978.

KORNDÖRFER, G. H.; ARANTES, V. A.; CORRÊA, G. F.; SNYDER, G. H. Efeito da aplicação de silicato de cálcio em solos cultivados com arroz de sequeiro. Revista Brasileira de Ciência do Solo, Viçosa, v. 23, p. 623-629, 1999.

KORNDÖRFER, G. H.; PEREIRA, H. S.; CAMARGO, M. S. Análise de silício: solo, planta e fertilizantes. Uberlândia; GPSi/ICIAG/UFU, 2004.
KORNDÖRFER, P. H.; SILVA, G. C.; TEIXEIRA, I. R.; SILVA, A. G.; FREITAS, R. S. Efeito da adubação silicatada sobre gramíneas forrageiras e características químicas do solo. Pesquisa Agropecuária Tropical, Goiânia, v. 40, n. 2, p. 119-125, 2010.

LIMA FILHO, O. F.; LIMA, M. T. G.; TSAI, S. M. O silício na agricultura. Informações Agronômicas, v. 87, p. 1-7, 1999.

LIMA FILHO, O. F.; TSAI, S. M. Crescimento $e$ produção do trigo e da aveia branca suplementados com silício. Dourados: Embrapa Agropecuária Oeste, Boletim de Pesquisa e Desenvolvimento Embrapa Agropecuária Oeste 41.2007. 34 p.

MA, J. F.; TAKAHASHI, E. Soil, fertilizer and plant silicon research in Japan. New York: Elsevier Science, 2002. $274 \mathrm{p}$.

MA, J. F.; YAMAJI, N. Functions and transport of silicon in plants. Cellular and Molecular Life Sciences, v. 65, n. 19, p. 3049-3057, 2008.

MA, J. F.; YAMAJI, N. Silicon uptake and accumulation in higher plants. Trends in Plant Science, Cambridge, v. 11, n. 8, p. 342-397, 2006.

MALAVOLTA, E.; VITTI, G. C.; OLIVEIRA, S. A. Avaliação do estado nutricional das plantas: princípios e aplicações. Piracicaba: POTAFOS, 1997. 319 p.

MARSCHNER, H. Mineral nutrition of higher plants. 2. ed. London: Academic, 1995. 889 p.

MAUAD, M.; CRUSCIOL, C. A. C.; GRASSI FILHO, H. Produção de massa seca e nutrição de cultivares de arroz de terras altas sob condições de déficit hídrico e adubação silicatada. Semina. Ciências Agrárias, Londrina, v. 32, n. 3, p. 939-948, 2011.

MORAES, S. R. G.; POZZA, E. A.; POZZA, A. A. A.; CARVALHO, J. G.; SOUZA, P. E. Nutrição do feijoeiro e intensidade da antracnose em função da aplicação de silício e cobre. Acta Scientiarum Agronomy, Maringá, v. 31, n. 2, p. 283-291, 2009.

POZZA, A. A. A.; CARVALHO, J. G.; GUIMARES, P. T. G.; FIGUEIREDO, F. C.; ARAÚJO, A. R. Suprimento do silicato de cálcio e a eficiência nutricional de variedades de cafeeiro. Revista Brasileira de Ciência do Solo, Viçosa, v. 33, p. 1705-1714, 2009.

PRADO, R. de M.; FERNANDES, F. M.; NATALE, W. Calcário e escória de siderurgia avaliados por análise foliar, acúmulo, e exportação de macronutrientes em cana-de-açúcar. Scientia Agricola, Piracicaba, v. 59, n. 1, p. 129-135, 2002a.

PRADO, R. M.; COUTINHO, E. L. M.; ROQUE, C. G.; VILLAR, M. L. P. Avaliação da escória de siderurgia e de 
calcários como corretivos da acidez do solo no cultivo da alface. Pesquisa Agropecuária Brasileira, Brasília, v. 37 , n. 4, p. 539-546, 2002b.

PRADO, R. M.; FERNANDES, F. M.; NATALE, W. Efeito residual da escória de siderurgia como corretivo de acidez do solo na soqueira de cana-de-açúcar. Revista Brasileira de Ciência do Solo, Viçosa, v. 27, n. 2, p. $287-$ 296, 2003.

RAFI, M. M.; EPSTEIN, E.; FALK, R. H. Silicon deprivation causes physical abnormalities in wheat (Triticum aestivum L.). Journal of Plant Physiology, v. 151, n. 4, p. 497-501, 1997.

RAIJ, B. VAN. Fertilidade do solo e manejo de nutrientes. Piracicaba: Internacional Plant Nutrition Institute, 2011. $420 \mathrm{p}$.

REIS, J. J. D.; ALOVISI, A. M. T.; FERREIRA, J. A. A.; ALOVISI, A. A.; GOMES, C. F. Atributos químicos do solo e produção da cana-de-açúcar em resposta ao silicato de cálcio. Revista de Ciências Agrárias, Lisboa, v. 36, n. 1, p. 3-9, 2013.

ROSSET, J. S.; LANA, M. C.; PEREIRA, M. G.; SCHIAVO, J. A.; RAMPIM, L.; SARTO, M. V. M. Frações químicas e oxidáveis da matéria orgânica do solo sob diferentes sistemas de manejo, em Latossolo Vermelho. Pesquisa Agropecuária Brasileira, Brasília, v. 51, n. 9, p. 1529-1538, 2016.

ROSSET, J. S.; LANA, M. C.; PEREIRA, M. G.; SCHIAVO, J. A.; RAMPIM, L.; SARTO, M. V. M.; SEIDEL, E. P. Carbon stock, chemical and physical properties of soils under management systems with different deployment times in western region of Paraná, Brazil. Semina: Ciências Agrárias, Londrina, v. 35, n. 6, p. 30-53, 2014.

RUPPENTHAL, V.; ZOZ, T.; STEINER, F.; MARIA, L. Y.; DALAZEN, D. Silicon does not alleviate the adverse effects of drought stress in soybean plants. Semina: Ciências Agrárias, Londrina, v. 37, n. 6, p. 3941-3954, 2016.

SAEG. Sistema para análises estatísticas e genéticas. Versão 8.0. Viçosa, MG: Universidade Federal de Viçosa, 1999.

SARTO, M. V. M.; LANA, M. C.; RAMPIM, L.; ROSSET, J. S.; WOBETO, J. R. Effects of silicate application on soil fertility and wheat yield. Semina: Ciências Agrárias, Londrina, v. 36, n. 6, p. 4071-4082, 2015.
SARTO, M. V. M.; LANA, M. C.; RAMPIM, L.; ROSSET, J. S.; WOBETO, J. R.; ECCO, M.; BASSEGIO, D.; COSTA, P. F. Effect of silicate on nutrition and yield of wheat. African Journal of Agricultural Research, v. 9, n. 11, p. 956-962, 2014a.

SARTO, M. V. M.; RAMPIM, L.; LANA, M. C.; ROSSET, J. S.; ECCO, M.; WOBETO, J. R. Atributos químicos do solo e desenvolvimento da cultura do trigo em função da adubação silicatada. Agrarian, Dourados, v. 7, p. 390-400, 2014b.

SARTO, M. V. M.; LANA, M. C.; RAMPIM. L.; ROSSET, J. S.; INAGAKI, A. M.; BASSEGIO, D. Effects of silicon ( $\mathrm{Si}$ ) fertilization on gas exchange and production in Brachiaria. Australian Journal of Crop Science, v. 10, n. 3, p. 307-313, 2016.

SARTO, M. V. M.; SARTO, J. R. W.; RAMPIM, L.; ROSSET, J. S.; BASSEGIO, D.; INAGAKI, A. M.; COSTA, P. F. Wheat phenology and yield under drought: a review. Australian Journal of Crop Science, v. 11, n. 8, p. 941-946, 2017.

SARTO, M. V. M.; STEINER, F.; LANA, M. C. Assessment of micronutrient extractants from soils of Paraná, Brazil. Revista Brasileira de Ciência do Solo, Viçosa, v. 35, n. 6, p. 2093-2103, 2011.

SORATTO, R. P.; CRUSCIOL, C. A. C.; CASTRO, G. S. A.; COSTA, C. H. M.; FERRARI NETO, J. Leaf application of silicic acid to white oat and wheat. Revista Brasileira de Ciência do Solo, Viçosa, v. 36, n. 5, p. 1538-1544, 2012.

SOUZA, R. T. X.; KORNDÖRFER, G. H.; WANGEN, D. R. B. Atributos químicos de solos influenciados pela substituição do carbonato por silicato de cálcio. Revista Brasileira de Ciência do Solo, Viçosa, v. 32, n. 4, p. 1563-1572, 2008.

ZANÃO JÚNIOR, L. A.; FONTES, R. L. F.; NEVES, J. C. L.; KORNDÖRFER, G. H.; ÁVILA, V. T. Rice grown in nutrient solution with doses of manganese and silicon. Revista Brasileira de Ciência do Solo, Viçosa, v. 34, n. 5, p. 629-1639, 2010.

ZUCARINI, P. Effects of silicon on photosynthesis, water relations and nutrient uptake of Phaseolus vulgaris under $\mathrm{NaCl}$ stress. Biologia Plantarum, v. 52, n. 1, p. 157-160, 2008. 